\title{
THE CULTURE-ORIENTED BIAS OF AFRICAN PHILOSOPHICAL INQUIRY
}

\author{
David A. OYEDOLA, MA \\ Department of Philosophy \\ Obafemi Awolowo University \\ Ile-Ife, Nigeria
}

\begin{abstract}
African philosophers with Levy Bruhlian disposition like Appiah, Masolo, and Wiredu posit that African philosophy is culture-biased. Some other African philosophers like Nkrumah, Janz, Hountondji, and Makinde assert that Africa's precolonial indigenous culture is ahistorical and the dependence of contemporary African philosophy on culture cannot be de-emphasized. However, these views, though opposing, undermine two things; the way African philosophy has chosen to divulge itself and the objectivity that is peculiar to African philosophy. Nevertheless, this study concedes that if by implication, what these views are saying is that African philosophy will have to sink because it is culture-biased; then, this study insists that any other philosophy (e.g., European philosophy) would have to sink. Precisely, there is no difference between any of the philosophies with respect to the fact that the interests of the European philosopher determine what he selects for investigation, just like what an African philosopher chooses to investigate and it is safe to speculate that these interests whether in the West or in Africa are culture-colored.
\end{abstract}

Keywords: African philosophy, European philosophy, Culture, Bias, Inquiry

\section{Introduction}

This study represents a departure from the Levy Bruhlian disposition where anthropology (the new science that replaced the old science of subject-object dichotomy, i.e., epistemology) became the tool for questioning the ratiocination of the "Other" (e.g., Africans). Furthermore, this study attempts to depart from another disposition which relegates African cultural inquiry or nullifies the identity of the Africans. The philosophers under the latter disposition include the likes of Kwame Appiah (Illusions of Race, 1992; Color Conscious: The Political Morality of Race, 1996; The Ethics of Identity, 2005; and Cosmopolitanism: Ethics in the World of Strangers, 2006) and Dismas A. Masolo (African Philosophy and the Post-colonial: The Misleading Abstractions about Identity, 1997). The Levy Bruhlian disposition posits that Africans, south of Sahara, lack the property of ratiocination, it further helps in dictating the mind and writings of many traditional, contemporary and academic Africans in Africa, the diaspora and some other African philosophers. However, Levy 
Bruhl's view, for Kwasi Wiredu, Odera Oruka, Olusegun Oladipo, Moses Makinde, Didier Kaphagawani, Barry Hallen, Peter Bodunrin, Paulin Hountondji, Placid Tempels, Moses Oke, Barry Hallen, Frantz Fanon, Robin Horton, Amilcar Cabral, and host of others, has dire implications on the postcolonial identity of Africa, Africans and African philosophy. Appiah and Masolo are of African origin but they have used their analytic training to nullify racial and identity concerns in their discourses. This nullification by Appiah and Masolo confirms the position that racial-identity, for Africans, is impossible. Their reason is because there is just one race; the human race. Thus, the postcolonial quest of Africa, Africans and African philosophy to have an independent racial identity has been put to rest because this quest has no greater importance than the global 'human race' (APPIAH 1992, 1996, 2005, 2006 and MASOLO 1997). For African philosophy to reclaim its stand, the ability to have something to profess in order to convince others needs urgency. Similarly, the postcolonial perception or impression that Africa (coupled with African philosophy) is not inferior needs to be proven. Thus, the post Levy-Bruhlian perception which persistently receives its support from some post-colonial professional or European trained Africans sees African philosophy as a field that confronts a certain difficulty; this difficulty is that it is culture-bias or traditionoriented. In resolving this problem, some African philosophers like Olusegun Oladipo (2002, 233), Moses Oke (2006, 337), Kwame Nkrumah (1974, 20), Odera Oruka (1991, 177), Peter Kanyandago (2003, 31-33), etc., have emphasized the need for historical retrospection in re-making a new Africa; while, some others like Bruce Janz (2003, 32), Kwasi Wiredu (1998, 195), Messay Kebede (2004, 129), Richard Bell (2002, 198), etc., maintain that contemporary African philosophy has come of age (no longer culture dependent); while some others like Moses Makinde (2010, 28-29), Didier Kaphagawani (1998, 86-87), Tsenay Serequeberhan (1998, 12), Niyi Osundare $(1998,29)$, etc., have postulated that Africa's precolonial indigenous culture cannot help in reigniting Africa's development, and that the training of professional African philosophers would aid a new modality of doing African philosophy.

Given that African philosophy needs to be re-assessed or rescued, the fundamental problem that it is culture-biased cannot be ignored. Since the culture-bias has become a plate upon which African philosophy is viewed, this study concedes that there cannot be a sufficient explication or defence that European philosophy, or any other philosophy, is not culture-bias too. 


\section{Culture-Bias and Culture-Neutrality: The Nature of African and European Cultural Investigations}

It is pertinent we turn, finally, to the difficulty that can be said to be confronting African philosophy because the culture to which we can say that the philosophers in African philosophy are committed not only colors the contents of their findings but also controls the assessment of the evidence on which they base their conclusion. Since African philosophers generally differ in their culture orientations, the "culture neutrality" that appears to be so pervasive in the European philosophy is therefore often held to be impossible in African philosophy. In the judgment of many European anthropologists, or some Western-trained professional African philosophers, it is accordingly absurd to expect African philosophy to exhibit the unanimity so common among philosophers in European philosophical history concerning what ought to constitute the problematic issues to be discussed in philosophy, the analytic methodology to be used, and the satisfactory explanations that are least expected of them. Let us examine some of the grounds that have been put forward for this contention. It will be easy to distinguish four groups of such reasons, so that our discussion will deal in turn with the asserted role of cultures in (a) the selection of difficulties, (b) the ascertainment of the profundity of their outcomes, (c) the approval of cultural facts, and (d) the appraisal of evidence.

\section{The Selection of Difficulties}

The reason, perhaps most frequently cited, is the fact that the things an African philosopher selects for investigation are determined by his own conception of what are culturally important values. According to one influential view, for instance, African philosopher deals with materials to which he attributes "cultural importance, consequence, or meaning," so that a "cultural-orientation" is inherent in his choice of material for investigation. John Ezeugwu's point that "it is not bad for the Africans to defend their philosophy and their origin, as against the claims and positions of the few African thinkers, who do not believe that African philosophy exists, and a great number of the Westerners who see nothing meaningful in their thoughts and ideas, but in doing so, they became biased and elevated their philosophy and relegated other philosophies to the background" $(2014,41)$, could not have been made in passing without a specific aim to resolve certain problems, whether those problems are derivative of some Africans or European anthropologists. Though, Ezeugwu could not have meant that African cultural inquirers have been prejudiced because they are cultural beings, yet he provided a classic statement which is calm, judicious and prescient. In his work, A Short History of African Philosophy, Barry Hallen, though, is a vigorous proponent of the view that "philosophy in any cultural context is not likely to be the easiest subject in the world," $(2002,1)$, however, 
its presentation can make it seem excessively technical and obscure in nature, and can frustrate understanding unnecessarily. This suggests that both philosophies (African and European philosophies) are situated in the culture which colours the contents of any of the findings on which their adherents base the conclusions of their different works.

The implication of John Ezeugwu and Barry Hallen's views can be said to be based on the cultural or contextual view of how philosophy in Africa has come to be distinct, and the way that it can be understood which may make the meaning of the terms used and the analysis to be technically obscure. African philosophy can sometimes be understood in the way some influential Anglotrained African professional philosophers like Kwasi Wiredu (How Not to Compare African Thought with Western Thought, 1998), Barry Hallen (A Short History of African Philosophy, 2002), Lucius Outlaw (African, African American, Africana Philosophy, 1998), Tsenay Serequeberhan (The Critique of Eurocentrism and the Practice of African Philosophy, 1997), Chukwudi Eze (Modern Western Philosophy and African Colonialism, 1998), Aime Cesaire (Discourse On Colonialism, 1997), Frantz Fanon (Racism and Culture, 1997, The Wretched of the Earth, 1997), Stephen Biko (The Definition of Black Consciousness, 1998) etc., have opined that African culture-laden discourse differs from its Western counterpart. Their view is that African philosophy should transcend the culture-laden discourse to develop the analytic and critical tendencies so as to compete meaningfully in the global philosophical discourse. However, he (Barry Hallen) have painted the notion that philosophy does not necessarily have to be analytic, rigorous and critical - he nevertheless argued that "the explanation I (Barry Hallen) can offer is that African philosophy should pay particular attention to a limited number of themes in Africa, so that they are deliberately isolated, and that they are extracted from their broader contexts, in order to facilitate relevant comparisons" $(2002,1)$. The perception of the meaningfulness of culture to us is the presupposition of its becoming an object of investigation for an African philosopher or investigator.

It is well-nigh self-evident to say that African philosophers, like philosophers in Europe or America, do not investigate everything, but direct their attention to certain selected portions of the inexhaustible content of concrete African reality. In addressing an aspect of this reality, Fanos Mangena's perception is that "for many years African philosophy has not been taken seriously by both Africans and Western philosophers alike. African philosophy has been disparaged and downgraded for failing to have, among other things, a coherent system of thought and a method that can be applied across the cultures of this world" $(2014,96)$. If we are to take Fanos Mangena very serious, his objective that "African philosophers should develop a system that is coherent and that can be applied world over, i.e., a logic on which 
African philosophy should sit instead of running away from their burning house only to refuge next door" $(2014,96)$, would mean one thing: the African ethnophilosophical approach to the body philosophy would become the black or African extraction which the Africans can be proud of. However, the problem that he (Mangena) may need to address is whether logic is divisible, where African logic, American logic, Asian logic, Arab logic, European continental logic, European analytic logic, etc., become possible. From the rules of modus ponens (MP), modus tolens (MT), repetition (R), double negation (DN), etc., it is perceivable that logic is logic, just as mathematics is mathematics, and that logic is not divisible into different cultures and continents. Its rules and methods are not culture-dependent. Given this problem, how can Fanos Mangena be rescued? The usage of the word 'logic' may not mean logic as a discourse of reasoning that follow rules but like a cultural way of life that people or outsiders can call the African way or rules of reference or inference. With this, Mangena's view that there is the need for a logic on which African philosophy should sit is admissible and relevant.

Moreover, let us accept the thesis, if only for the sake of the argument, that an African philosopher addresses himself exclusively to matters which he believes are important because of their relevance to his cultural-based values. It is not clear, in a way, why the fact that an investigator selects the materials he studies in the light of problems which interest him, and which seem to him to bear on matters he regards as important, is of greater moment for the logic of African inquiry than it is for the other branch of inquiry outside Africa. The things that an African philosopher selects for study with a view to determining the conditions or consequences of their existence may indeed be dependent on the indisputable fact that he is a cultural being.

In short, there is no difference between any of the philosophical dispositions (be it African or European) with respect to the fact that the interests of an African philosopher determine what he selects for investigation. But this fact represents no obstacle to the successful pursuit of objectively controlled inquiry in any branch of study or within each branch of study. For example, an African social and political philosopher may be interested in the nature of election rigging, or an African philosopher may be interested in the spiritual bond between twins and the effects it has on the immediate family and environment, while an American philosopher may be interested in the reason why the food that teenagers eat causes obesity. This does not presuppose any means of relative culturality, but it presupposes the view that there exists in each disposition an iota of objectivity which may not need to overlap or be found synonymous. 


\section{The Ascertainment of the Profundity of their Outcomes}

A more substantial reason commonly given for the culture-oriented character of African philosophy is that, since an African philosopher is himself affected by considerations of right and wrong in the particular African culture or in the African subject that he is investigating, his own notion of what constitutes a satisfactory African order and his own standard of personal and African form of philosophical disposition enter, in point of fact, into the analyses of African phenomena. In this respect, the veracity of the truth of African philosophy must be judged by admittedly "relative standards, i.e., in terms of the ends sought or the standards employed by the African society or philosopher concerned, rather than in terms of the European or American philosopher's own criteria. Ernest Nagel's description that, "yet, the history of human thought has led not to one philosophy but to several" (1968, 100), implies that the cultural attitudes implicit in the African ways of thinking will differ from that of its European counterpart, and sometimes conflict. The reason why there may be conflict between African and European dispositions of what should constitute a philosophical objectivity rests on, (i) the presupposition that there exist differences in what they portend and potentate. An implication can be derived here; what the African philosopher selects for investigation will remain relative to his culture. The same is applicable for European or American philosopher; and, (ii) they (African and European philosophers) sought to achieve the 'end' by the means possible or through different criteria. Thus, there are basic judgments which we cannot do without in African philosophy, and which clearly do not express a purely personal philosophy of the enquirer or African values arbitrarily assumed. Rather, what African philosophers select for investigation grow out of the history of thought in Africa, from which the anthropologist of European descent can seclude himself as little as can anyone else.

It has often been noted that the study of African phenomena receives much of its impetus from a strong moral and cultural zeal, so that many ostensibly "objective" analysis in African philosophy are in fact disguised recommendations of African first-order system. Moses Oke's explication may have to be considered here. For him, "it is common for cultures to fade away and be replaced by new or old ones, and for cultures to vary from society to society and from age to age" (OKE 2006, 332). But as I would like to moderately express the point, a support for Moses Oke's view would not be misplaced; an African philosopher, I believe, cannot wholly detach the unifying cultural structure that, as an analytic, methodologist or culturalist, guides his detailed investigations of African problems, from the unifying structure which, as an African's ideal, he thinks ought to prevail in African affairs and hopes may sometimes be more fully realized. His African theory in philosophy is thus 
essentially a program of action along two lines which are kept in some measure of harmony with each other by that African problem-problem in assimilating African facts for purposes of systematic understanding, and problem in aiming at progressively molding the distinct African pattern, so far as he (the African philosopher) can influence it, into what he thinks it ought to be.

It is surely beyond serious dispute that African philosophers do in fact often import their own culture into their analyses of African phenomena. Moses Oke's reason for this is that "the indigenous social culture was superimposed upon Africa and Africans by alien colonialist cultures leading to a confused cultural amalgam in which Western conceptions of the good have been imposed upon African thought and conduct" $(2006,332)$. The conscious design of separate cultures and cultural understanding, as implied using Oke's analysis, will become a device to express the tendency of maturity in each culture or part of nature. (It is also undoubtedly true that even thinkers who believe human condition can be studied with the culture neutrality characterizing every inquiry into objective activities, and who often pride themselves on the absence of culture orientation from their own analyses in African philosophy, do in fact sometimes makes judgments from their own analyses of African condition. Even if culture predications are assumed to be inherently capable of proof or disproof by European philosophical tradition, at least some of the differences between African philosophers involving culture-orientation are not in fact resolved by the procedures of controlled inquiry.

It does not appear so easy in African philosophy to prevent, in any event, aversions, hopes and fears from coloring the conclusions that philosophers will arrive at. It has taken countless years of efforts to develop habits and techniques of investigation which help safeguard philosophical dispositions and inquiries in European philosophical traditions against the intrusion of irrelevant personal factors; and even in this case, the protection received has not created an infallible or conclusive framework. Thus, the difficulties it creates for achieving objective analyticity in African philosophy must be admitted.

Admittedly, steps must be taken to identify a culture bias when it occurs at the maximum, and to minimize if not to eliminate completely its perturbing effects. What the second reason is analyzing is that it would be no less absurd to conclude that reliable knowledge of human affairs is unattainable merely because inquiry in African philosophy is frequently culture-oriented. What this means is that relative standards by different investigators are used (ends sought, standards employed), whereas there are no absolute standards (we only have evaluation of the end result only in different continents where different investigators carry out their study). 


\section{The Approval of Cultural Facts}

There is a more sophisticated argument for the view that African philosophy cannot be culture-free. It maintains that the distinction between fact and culture assumed in the preceding discussion is untenable when purposive African culture is being analyzed, since in this context culture enter inextricably into what appear to be purely factual statements. Accordingly, those who subscribe to this thesis claim that a culture-neutral African philosophy is in principle impossible, and not simply that it is difficult to attain. For if value and culture are indeed so fused that they cannot even be distinguished, cultural judgments cannot be eliminated from African philosophy, unless all predications are also eliminated from them, and therefore, unless other philosophies that are not of Africa completely disappear. In this regard, Messay Kebede's belief in the African form of cultural modernity cannot be ignored. He is of the view that, "the involvement of African philosophical, cultural or traditional discourse provides the proof that values and spiritual pursuits are most active in making of African modernity" (2004, 12-13). His view describes one thing; the African reaction to appearance of objectivity raises questions of the kind compelling us to upgrade our understanding of development and modernity instead of relying on conventional answers (KEBEDE 2004, 34). A conventional answer, to a great extent, is the belief that African philosophy is not culture-free. As African philosophy is not culture free, it does not mean that it is inferior and it does not mean that it has to be subdued or become a second-string form of philosophical or cultural discourse.

For example, it has been argued by Richard H. Bell (1997, 2002), Peter Bodunrin (1984), and Robin W.G. Horton (1997), that the African philosopher must distinguish between traditional and undesirable forms of African system, on failing in his plain duty to present African condition truthfully and faithfully, the prohibition against culture-judgments in African philosophy would lead to the consequence that we are permitted to give a strictly factual description of philosophical issues that can be seen in European philosophy, while Odera Oruka (1998, 177), Niyi Osundare (1998, 229-230), Bruce Janz (2003, 34-6), and Kwasi Wiredu (1998, 194-5) assert that we would not be permitted to speak of the cruelty that has once happened to Africa during colonialism and the neocolonial effects of Western friendship with Africa on the psyche of Africans. A political scientist is allowed to see things from his perspective, while a philosopher historian is permitted to see things from the perspective of analyticity and do a critique of how imagination can be used to take a look at historical event. What may be claimed to be a straightforward view in European philosophy may be different in African philosophy.

Moreover, the assumption implicit in the recommendation discussed above for achieving culture-neutrality in European philosophy is often rejected 
as hopelessly naïve, it will be recalled, that relations of means to ends can be established without commitments to these ends, so that the conclusions of African philosophical inquiry concerning culture are objective views of life which make conditional rather than categorical assertions about culture. This is because, the choice men make between alternative means of obtaining a given end depends on the cultural view they ascribe to those alternatives.

If there is any proposition made that African philosophy is culture-laden, it does not entail the conclusion, that, in a manner unique to the study of African philosophy, value and culture are fused beyond the possibility of distinguishing between them. It is worthy to note that, the claim that there is such a fusion and that a culture-free African philosophy is therefore inherently absurd, confounds two quite different senses of the term "culture judgment": the sense in which a culture judgment expresses approval or disapproval either of some religious, moral or social ideal, or of some cultural view, of or some cultural action (or cultural institution) because of a commitment to such an ideal; and the sense in which a culture judgment expresses an estimate of the degree to which some commonly recognized (and more or less clearly defined) type of cultural action, object, or institution is embodied in a given stance (See, WIREDU 1998, 307-8; WIREDU 1998, 193-4).

Furthermore, to make any decision, an investigator, whether an African or Euro-American, must judge whether the evidence warrants the conclusion set to be made whether in African philosophy or European philosophical tradition. Nonetheless, when an investigator reaches a conclusion within the cultural framework where he is doing his investigation, he can therefore be said to be making a specific "cultural value-judgment", in the sense that he has in mind some standardized type of cultural condition designated, and what he knows and calls the object in view and that he assesses what he knows about the specimen with the measure provided by this assumed standard.

On the other hand, the African philosopher may also make a quite different sort of cultural judgment, which asserts that, since a cultural object under consideration has diminished powers of remaining under continuous examination, it is an undesirable condition. An African philosopher with specific interest in Yoruba thought may be interested in how some events are tagged cultural and metaphysical at the same time. Take for instance, a person's iwa (character) which makes an individual meaningful or meaningless in the human society, is what makes people to have good memory of the individual after his demise. Thus, how has the concept of iwa as character become existential? The response may lie in the notion that the concept of iwa has two attributes (GBADEGESIN 1998, 303-5): the character aspect where it makes an individual to relate with other individuals in the moral community and the existential aspect which creates a good or bad memory and which allows 
judgment to be passed on the person. Like the African philosopher: (Yoruba example), a Euro-American philosopher may be interested in characterizing certain objects in his field of research as philosophical, psychological or natural; but, also like the African philosopher, he is in addition expressing his cultural approval or disapproval of the characteristics he is ascribing to his research. The difficulties that African philosophers with the European counterparts raise provide no compelling reasons for the claim that a culturally neutral African philosophy is inherently impossible.

\section{The Approval of Evidence}

There remains for consideration the claim that a culture-free European philosophy is impossible, because culture commitments enter into the very assessment of evidence by European philosophers, and not simply into the contents of the conclusions they advance. This is typical of Moses Makinde's African Philosophy: The Demise of a Controversy. Similarly, some African thinkers tend to believe in this form of framework. Precisely, Kwame Nkrumah's Consciencism (1998), Julius Nyerere's Ujamaa: The Basis of African Socialism (1971), Obafemi Awolowo's Democratic Socialism (2010, 170-205), Nelson Mandela's Interventionism in Apartheid (2013), and so forth, are proponents thereof. Moses Makinde, in his work, African Philosophy: The Demise of a Controversy, asserts that the analytic school's view of philosophy is just one of many views and their conception of the nature and subject matter of philosophy is personal to members of that school (2010, 23). He says, "African thought hold positions quite similar to many ancient and recent European philosophers" (MAKINDE 2010, 28-9). This assertion helps to understand the notion that culture commitments enter into the very assessment of evidence by European and African philosophers, and not simply into the contents of the conclusions they advance. If culture commitments do not enter into the contents of the conclusions that European philosophers advance, then, the conceptions of the culture held by an African philosopher of what constitute cogent evidence or sound intellectual workmanship are the products of his cultural education and his place in the society, and are affected by the social cultural values transmitted by his training and associated with his cultural position; accordingly, the cultural values to which an African philosopher is thereby committed determine which statements he accepts as well-grounded conclusions about African cultural affairs. Thus, the differences between African philosophers in respect to what they accept as credible can sometimes be attributed to the influence of cultural, religious, and other kinds of bias.

No matter how investigations are conducted in the African and European ways, the culture-oriented bias of each continent would help where the evidence will be taken and in situating where the outcome would be placed. Each culture 
helps in giving reliable instances or knowledge about the world. The problem is just that these different cultural environments would help research in a lot of ways; the world will be seen from different angles just like an elephant will be viewed from different angles. Inquiries are not meant to be conducted in the same way using the same methodology. African cultural life differs from the European lifestyle, in the sense that, if childless marriages are to be examined using the European condition and the African condition, different results will be arrived at because their societies and belief-system strictly differs. A relational form of objectivity between African perception of a childless marriage and the Euro-American perception of a childless marriage, which is called relationism, to a great extent, cannot be achieved (see, JANZ 2003, 36-7). In any way that we may want to analyze the issue at hand, it suffices to say that the cultural conclusion that an African philosopher would reach is marked by 'objectivity' because of the peculiarity of his cultural environment, where the same is applicable to the European investigator under the European cultural condition.

In brief, the various reasons we have been examining for the endemic impossibility of securing objectivity where each culture has its own standard of objectifying issues do not establish what many European philosophers purport to establish, even though in some instances, an European philosopher or trained professional African philosophers direct attention to undoubtedly important practical difficulties frequently encountered in the African cultural discourse. However, Peter Kanyandago differs from this conclusion. The trend of westernization of Africa, he says, "has become very pervasive," because inculturation implies a re-appropriation of cultures (KANYANDAGO 2003, 3233). Because of the western dominated African life or re-appropriation of African culture, he rejected the African form of humanity. This, to a great extent, cast doubt on any form of objectivity which could have been reached by the African cultural inquirers and environment. However, there is a response from William Emmanuel Abraham to Kanyandago's doubt. In trying to show that each culture has different understanding concerning the nature of man coupled with his ability to conduct cultural inquiry, he (William Abraham) pointed out that "if possession of reason is part of our nature (or, if reasoning is part of the description of how people conduct their affairs or cultural investigation in different cultures), then, we cannot be enslaved by reason" (ABRAHAM 1966, 80-1), hence, reason is unworthy to create cultural inferiority. What William Abraham purport to establish is that; reason is possible in different cultures, because man cannot be enslaved to reason so as to be led to casting doubt on what are the end-products of what 'others' carry out. William Abraham's view, to a great extent, reflects the claim of this study. 


\section{The Grounds for the Objective-Status of African Philosophy}

For as much as this study has examined some of the grounds that have been put forward for the contention that African philosophy is culture-prejudiced, it was quite easy to distinguish the four groups of such reasons, such that the discussion, thus far, has helped in dealing in turn with the asserted role of culture in the choice of problems, the determination of the contents of conclusions, the acceptance of cultural facts, and the appraisal of evidence between what the African and European investigators do.

Emevwo Biakolo in the Categories of Cross-cultural Cognition and the African Condition, asserts that, it is in consonance with the pattern of growth and development of the new science of anthropology which replaced the old science of subject-object relations that the determining factor becomes the issue of race $(1998,1)$. Race is used based on the particularity of Africa as distinct from Europe. Thus, the issue of objectivity, as Biakolo has helped us to discover, paves the way for the factors that makes African investigator to be easily distinguished from the European counterpart when it comes to whatever is chosen to be investigated. If we assert that there is no cultural difference, or that races do not exist (as Kwame Appiah asserts in his works of 1992, 1996, 2005 and 2006), then, we need to heed Emevwo Biakolo's warning that "an ingenuity will be revealed which will help us to further confirm that there is a political project behind the western construction of the cultural paradigms of the "Other" (1998, 1). If Biakolo's paradigm (which Bruce Janz (2003, 34-38) further reiterates) stands, it will be consistent with the notion that African culture, African philosophy or black race has no objective standing in the universe. But if Biakolo's ingenuity (which is a rejection of Appiah's assertion) is followed, it will presuppose the notion that there is no fundamental difference between what African investigators investigate and what European investigators try to investigate.

We may want to consider it not quite necessary to follow the line of the argument that has been put forward. The nature of this unnecessariness may arise from a critic's view as predicated upon Kwame Appiah's assertion that there are no races: there is nothing in the world that can do all we ask race to do for us $(1992,45)$. Be it as it may, the implication that his claim creates is that there is no need of classifying people into few races because classifying books in the library would not help us in reflecting or knowing the deep facts about books (APPIAH 1992, 38). For as much as this claim may help in advancing the idea of globality, it can be used in boxing Appiah to a corner. He fails to acknowledge the mental ascription of culture; where people are so biased about who they are, where they come from, the values they represent, what they need to say or withhold, and how they must communicate. There is still a whole lot to 
say about different but not opposing cultures and about what makes Africa distinct as Africa and not what makes Africa become a collegiate with Europe.

In his work, Old Gods, New Worlds, Kwame Appiah claims that for the African intellectual, of course, the problem is whether - and, if so, how - our (African) cultures are to become modern. He concludes by saying that, neither of us (Africa and Europe) will understand what modernity is until we understand each other $(1992,107)$. It is somewhat obvious that despite his (Appiah's) initial claim that there are no races, he asserts in another work that Africa and Europe needs to understand each other. What will be the nature and scope of this understanding? Entering into Appiah's mind using his earlier work, The Illusions of Race would presuppose a confusing analogy. There are no races, he (Appiah) said, and now, Africa and Europe need to understand each other, is a presupposition of (i) confusion, and (ii) that races exist. In conclusion, it means an African investigator differs from his/her European counterpart, that Africa differs from Europe, and that any European anthropologist cannot conclusively understand why Africans choose to carry out a particular thing in their culture. For example, a European investigator or anthropologist cannot understand why Africans (e.g., some parts of the Yoruba people) choose to erect two effigies to represent twins (ère ìbejì) and decide to give the cultural or lineage panegyrics of these effigies. To arrive at a conclusion that such practice is pre-logical is to be preposterous. Janheinz Jahn observes in Muntu: African Culture and the Western World that "all activities of men, and the movements in nature, rest on the word, on the productive power of the word, which is water and heat and seed and Nommo, that is, life force itself .... The force, responsibility, and commitment of the word, and the awareness that the word alone alters the world .... In traditional African culture, a new born child is a mere thing until his father gives and speak his name" (1961, 128). It is now commonly known that to speak of other cultural understanding about a particular thing as preposterous because of pre-logicality, is to be mistaken. Janheinz Jahn's opinion, in this respect, is that "the African tradition as it appears in the light of neo-colonial culture may be a legend - but it is the legend in which African intelligence believes" $(1961,19)$. This presupposes one thing that this study affirms; the African cultural understanding and analysis of a specific thing is neither preposterous, religious, savagery, archaic, inferior, brute nor pre-logical. The idea that the African cultural understanding or analysis of a thing or situation should be found or done within the limit of the cosmopolitan or global world view is an attempt to encourage reductio ad absurdum. But, this is Pecksniffian in nature. Janheinz Jahn's assertion is that the position of the West, which sees African culture as being doomed to destruction or homogenization, is mistaken. African culture, as Janheinz Jahn posit, is evolving into a rich and independent civilization that is capable of incorporating 
those elements of the West that do not threaten its basic values. Though Julius Nyerere's in Ujamaa: The Basis of African Socialism (1971, 91-95) lend support to Jahn Janheinz's position by asserting that it is the attitude of the mind to help one another in the communal African society and to help develop the African socio-cultural values that best describe the African condition, however, the problem with Nyerere's Ujamaa is that it is a caricature of Scientific Socialism (Marxism), which proposes that socialism must come through proletarian revolution within an already developed capitalist state.

In this regard, the distinctiveness of the culture and cultural understanding of the African condition as exhibited and explicated by Kwame Anthony Appiah in Old Gods, New Worlds (1998, 245-74), B. Du Bois in The Conservation of Races (1998, 269-74), Richard H. Bell's Understanding African Philosophy: A Cross-Cultural Approach to Classical and Contemporary Issues (2002, 197-220), Robin William G. Horton's Patterns of Thought in Africa and the West: Essays on Magic, Religion and Science (1997), etc., help in asserting the objective status of what African investigators do with cultural facts as different from what European investigators do with the tools of philosophical analysis.

In African, African American, Africana Philosophy, Lucius Outlaw opines that "philosophizing is inherently grounded in socially shared practices, not in transcendental rules. When we view philosophical practices historically, sociologically, and comparatively, we are led inescapably to conclude that philosophical practice is inherently pluralistic, and all philosophical ideals are local to communities of thinkers. Since African peoples are ethnically - hence culturally - diverse and geographically dispersed, very important aspects of these ethnic and geographical diversities were fueled, in significant part, by the incursions of Europeans and others into Africa" $(1998,29)$. If Lucius Outlaw's framework is encouraged, then, the ground for separate investigations between African investigators and their European or American counterparts would not be seen as prejudices but distinct fields of inquiry.

There may be other ways of analyzing Appiah's view that there are no races and DuBois' counter-claim that individual races are to be conserved because they have distinct messages to deliver to the world. However, Emevwo Biakolo's view that it is the Western political project that actually distinguishes the world of the "Other", and Leopold Senghor's claim that "Negroid civilization had flourished in the Upper Palaeolithic Age, where the Neolithic Revolution could not be explained without them" (1998, 439), are clear representations of distinct viewpoints which we must recognize as not conflicting. These views, Leopold Senghor maintains that, they "set us on the way to racialism" (1998, 439). Similarly, Tsenay Serequeberhan's view that "the closing years of the twentieth century are bound to be for Africa and 
Africans for a time of prolonged, deep reflection and self-examination" (1998, 9), Kwame Nkrumah's suggestion of a cultural revivalist solution that will revive the African cultural values of the past into the present $(1974,79)$, and Henry Olela's position that "the authentic theoretical foundation of African diaspora's experience is African" (1998, 43), serve as, (i) counter-objection to Kwame Appiah's claim in the Illusions of Race (1992), and as explicated in his recent work, Color Conscious: The Political Morality of Race (1996), where he defended the view that the concept of race is a mistaken American idea (APPIAH and GUTMAN 1996, 32); The Ethics of Identity (2005), where he defended the term 'collective identity'(APPIAH 2005, 21-22); Cosmopolitanism: Ethics in a World of Strangers (2006), and (ii) a major boost to aid the notions that there is distinctive Africanness in the way African philosophy has chosen to divulge itself, and that, there is the objectivity that is peculiar to African philosophical inquiry or investigation.

\section{Conclusion}

This study does not represent an attempt to split philosophical or cultural investigation among different cultures, as it does not also aim to conclude that cultural investigation is universal in nature and scope. What it aims to produce is a sort of relativism which would not damage the essentialist discourse of putting universal attributes behind human acts, behaviours and plans. Diogenes Laertius's claim as espoused by Appiah that "he (Diogenes) is a citizen of the world" has long been laid to rest. The shortcomings that World War I could not address gave birth to World War II; Al Qaeda dominates the East of the globe based on what the perpetrators deem as religious and political marginalization; colonialism took place in Africa and the socio-political and economic effects are still on-going in the lives of the Africans and in the activities of the African countries, and so on, as we can count. The conclusion of this study that there is distinctive Africanness in the way African philosophy has chosen to divulge itself, and that, there is the objectivity that is peculiar to African philosophical inquiry cannot walk hand-in-hand with Appiah's fear, which is that relativism gave birth to the separation between values and facts and this could spell doom for cosmopolitanism and its core values. However, it is important we note that no matter what Kwame Appiah may concede in his works, what an African investigator chooses to investigate, will always be consistent with his cultural world-view. This is because each specific human race or continents have their beliefs which have guided their relationship with 'others'. However, this study concedes that what a European investigator chooses to investigate will be consistent with his understanding of the world around him just like an African investigator who inquires about the culture or world around him. 


\section{Relevant Literature}

1. ABRAHAM, William. [The Mind of Africa], 1966. University of Chicago Press: Illinois, Chicago. Paperback.

2. APPIAH, Kwame. [Cosmopolitanism: Ethics in a World of Strangers], 2006. W.W. Norton \& Company: New York. Paperback.

3. _- "Old Gods, New Worlds," [In My Father's House: African Philosophy in the Philosophy of Culture], pp107-136, 1992. Oxford University Press: Oxford. Paperback.

4. _ . [The Ethics of Identity], 2005. Princeton University Press: Princeton. Paperback.

5. _ . "The Illusions of Race," [In My Father's House: African Philosophy in the Philosophy of Culture], pp28-46, 1992. Oxford University Press: Oxford. Paperback.

6. GUTMAN, A. [Color Conscious: The Political Morality of Race], 1996. Princeton University Press: Princeton. Paperback.

7. BELL, Richard. [Understanding African Philosophy: A Cross-Cultural Approach to Classical and Contemporary Issues], 2002. Routledge: London. Paperback.

8. BIAKOLO, Emevwo. "Categories of Cross-Cultural Cognition and the African Condition," [The African Philosophy Reader, PIETER, Coetzee and ABRAHAM, Roux Eds.], pp1-14, 1998. Routledge: London. Paperback.

9. BODUNRIN, Peter. "The Question of African Philosophy," [African Philosophy: An Introduction, $\quad$ Richard, WRIGHT Ed., $3^{\text {rd }}$ edn.), pp1-24, 1984. University Press of America: Lanham. Paperback.

10. DU BOIS, William Edward. "The Conservation of Races," [African Philosophy: An Anthology, Chukwudi, EZE Ed.), pp269-274, 1998. Blackwell Publishers: Oxford. Paperback.

11. EZEUGWU, John. "Ethnocentric Bias in African Philosophy vis-à-vis Asouzu's Ibuanyidanda Ontology," [Filosofia Theoretica: Journal of African Philosophy, Culture and Religions], pp41-49, Jan-Jun, 2014. Vol 3. No 1. Paperback. 
12. GBADEGESIN, Segun. "Individuality, Community, and the Moral Order," [The African Philosophy Reader, PIETER, Coetzee and ABRAHAM, Roux, Eds.], pp292-305, 1998. Routledge: London. Paperback.

13. HALLEN, Barry. [A Short History of African Philosophy], 2002. Indiana University Press: Bloomington, IN. Paperback.

14. HORTON, Robin. [Patterns of Thought in Africa and the West: Essays on Magic, Religion and Science], 1997. Cambridge University Press: Cambridge, MA. Paperback.

15. JAHN, Janheinz. [Muntu: African Culture and the Western World], 1961. The Groove Press: Chicago. Paperback.

16. JANZ, Bruce. "Between the Particular and the Universal: Cultural Inquiry as the Encounter between Anthropology and Philosophy," [Polylog: Forum for Intercultural Philosophy], pp30-37, 2003. Vol 4. Web.

17. KANYANDAGO, Peter. "Rejection of the African Humanity: Search for Cultural Re-Appropriation," [African Spirit and Black Nationalism: A Discourse in African American Studies, ZENEBU, Falaiye Ed.], pp30-50, 2003. Foresight Press: Lagos. Paperback.

18. KAPHAGAWANI, Didier. "What is African Philosophy?", [The African Philosophy Reader, PIETER, Coetzee and ABRAHAM, Roux, Eds.], pp86-98, 1998. Routledge: London. Paperback.

19. KEBEDE, Messay. "The Future as Forward Movement into the Past: The Constructedness of Identity," [Africa's Quest for a Philosophy of Decolonization], pp12-18, 2004. Vol 42. No 5. Rodopi:

New York. Paperback.

20. MAKINDE, Moses. [African Philosophy: The Demise of a Controversy], 2010. Obafemi Awolowo University Press: Ile-Ife. Paperback.

21. MANGENA, Fainos. "In Defence of Ethnophilosophy: A Brief Response to Kanu's Eclecticism," [Filosofica Theoretica: Journal of African Philosophy, Culture and Religions], pp96-107, Jan-Jun, 2014. Vol 3. No 1. Paperback.

22. MASOLO, Dismas. "African Philosophy and the Postcolonial: Some Misleading Abstractions about Identity," [Postcolonial 
African Philosophy: A Critical Reader, Chukwudi, EZE Ed.), pp283300, 1997. Blackwell Publisher Inc: Cambridge, MA. Paperback.

23. NAGEL, Ernest. "The Value-Oriented Bias of Social Inquiry," [Readings in the Philosophy of Social Sciences, Martin, BRODBECK Ed.), pp98-113, 1968. Macmillan Publishing Co. Inc: New York. Paperback.

24. NKRUMAH, Kwame. [Consciencism], 1974. Panaf: London. Paperback.

25. NYERERE, Julius. [Ujamaa - The Basis of Socialism], 1971. Oxford University Press: Oxford. Paperback.

26. OKE, Moses. "Cultural Nostalgia: A Philosophical Critique of Appeals to the Past in Theories of ReMaking Africa," [Nordic Journal of African Studies], pp332-343, 2006. Vol 15. No 3. Paperback.

27. OLELA, Henry. "The African Foundations of Greek Philosophy," [African Philosophy: An Anthology,

Chukwudi, EZE Ed.], pp43-49, 1998. Blackwell Publishers: Oxford, CA. Paperback.

28. ORUKA, Odera. "Sagacity in African Philosophy," [Readings in African Philosophy, Sophie, OLUWOLE Ed.], 1991. Mass-tech Publishers: Lagos. Paperback.

29. OSUNDARE, Niyi. "Squaring Up to Africa's Future: A Writer's Reflection on the Predicament of a Continent," [Remaking Africa: Challenges of the Twenty-First Century, Olusegun, OLADIPO Ed.], 1998. Hope Publications: Ibadan. Paperback.

30. OUTLAW, Lucius. "African, African American, Africana Philosophy," [African Philosophy: An

Anthology, Chukwudi, EZE Ed.], pp23-42, 1998. Blackwell Publishers: Oxford. Paperback.

31. SENGHOR, Leopold. "Negritude and African Socialism," [The African Philosophy Reader, PIETER,Coetzee and ABRAHAM, Roux Eds.], pp438-448, 1998. Routledge: London. Paperback.

32. SEREQUEBERHAN, Tsenay. "Philosophy and the Post-Colonial Africa," [African Philosophy: An Anthology, Chukwudi, EZE Ed.), pp9-22, 1998. Blackwell Publishers: Oxford. Paperback. 
33. WIREDU, Kwasi. "How Not to Compare African Thought with Western Thought," [African Philosophy: An Anthology, Chukwudi, EZE Ed.), pp193-199, 1998. Blackwell Publishers: Oxford. Paperback. 